\title{
Chapter 6 \\ Mobility and Migration in Mediterranean \\ Europe: The Case of Agro-pastoralism
}

While most of the existing literature on rural migrations focuses on immigrant workers in intensive agricultural systems, this work tries filling existing gaps by addressing more marginal and remote rural settings. The mountainous, inner and island territories that cover a large part of the Mediterranean are particularly affected by intense demographic decline, land abandonment and problems of generational renewal, posing important questions concerning the sustainability of local development.

The agro-pastoral systems that characterize these settings provide a relevant observatory to explore and disentangle rural migratory dynamics. In these areas the presence of immigrant shepherds represents a critical asset to maintain local farms, villages and territories alive and productive. By analysing the reconfiguration of human and natural landscapes in agro-pastoral systems of Greece, Spain and Italy, we provide a framework to assess the contribution of immigrants in maintaining and reproducing European rural societies.

\subsection{Introduction}

With a view to disentangle the contributions of immigrant communities to rural development, in this chapter we assess in deeper detail the relevance of foreign workers in agro-pastoralism.

Historically, agro-pastoralism - the extensive breeding of mostly sheep, goats and cattle associated to farming activities - is a traditional form of territorial management in marginal area of Mediterranean Europe. It provides valuable products and precious socio-ecosystem services, which are an integral part of food production and natural resource systems.

Shepherding, its practices and symbols are a traditional feature of all Mediterranean cultures; transhumance routes cut across EUMed territories creating synergies and enhancing economic integration; the wool economy has been a main driver of 
regional development for centuries. Animal proteins in the form of meat and milk products have become more relevant in recent decades, associated to several ecosystem services that are being increasingly acknowledged; most natural parks and reserves in the region are superimposed with historical agro-pastoral settings.

Agro-pastoralism is central especially in marginal rural settings, which constitute about half of the Mediterranean territories. Such territories are associated with lower income and employment opportunities, as well as with limited access to social, cultural and institutional services, pushing younger generations to move away in search of better options. Intense demographic decline, land abandonment and generational renewal represent important questions for the future of sustainable rural development.

Paradoxically, as it will be discussed, agro-pastoralism is increasingly appreciated by the European society for its products and services even though it is decreasingly practiced by its citizens. This paradox is currently resolved through the growing presence and contribution of immigrant shepherds. As farm labour intensifies and socio-economic conditions have hardly improved, foreign workers have become strategic for the survival of agro-pastoral enterprises, and for the marginal and depopulated territories.

By analysing the reconfiguration of human and natural landscapes in the agropastoral systems of Spain, Greece and Italy, we provide a framework to assess the contribution of immigrants in maintaining and reproducing European rural societies. Data, estimates and sources are specifically for sheep and goat farming, and for markets related to ewe's milk and sheep cheese, as these are typically associated to agro-pastoral systems in the region.

\subsection{Contemporary Changes in Mediterranean EU Agro-pastoralism}

To understand the increasing role of immigrant workers in agro-pastoralism, it is necessary to introduce the characteristics of agro-pastoral systems and their recent changes and dynamics.

Historically, Mediterranean rural settings are characterised by agro-pastoral systems. Due to the climatic and territorial features of the region, Mediterranean agricultural systems were typically extensive and oriented to self-consumption, muntifunctionality and polyculture; these consist of cereals such as wheat and barley, while vineyards, olive and other fruit trees are part of the countryside, especially where the steepest terrain makes it difficult to farming cereals. Associated to these crops, the extensive breeding of mostly sheep, goats and cattle represents a typical complementary component of local rural livelihoods (Campbell 1964; Pernet and Lenclud 1977; Le Lannou 1979; Ravis-Giordani 1983; Meloni 1984; Mattone and Simbula 2011). 


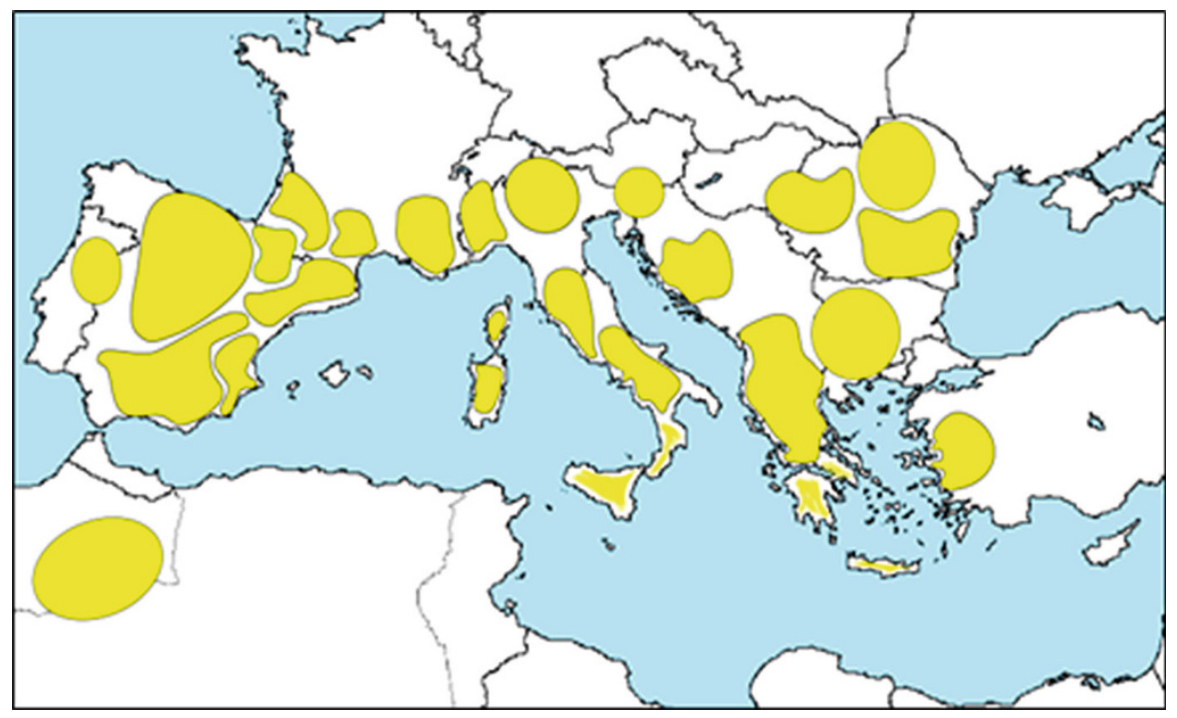

Fig. 6.1 Areas of main transhumant systems in the Mediterranean. (Source: Own elaboration from Braudel (1982))

\section{Box: Mediterranean Transhumances}

In the Mediterranean, breeding sheep and goats is often associated with the practice of transhumance, the seasonal mobility of flocks, which makes it possible to adapt flocks' productive and reproductive performances to the rhythm of the seasons and the availability of pasture - cooler inner, mountain pastures during the summer and milder coastal areas or valley bottoms in winter times. In complementarity with sedentary agricultural activities, this system enables making the best use of the agro-ecological diversity and of the marked seasonality of the region. Transhumance has been instrumental for the management and the governance of extended territories. For example, the Mesta systems in Spain, and the Dogana in Italy served the lucrative trade of wool, while also contributing to integrating territories, economies and cultures (Braudel 1982 - also refer to Fig. 6.1). During the last century, these systems began to fade due to important changes in global economy, regional trade and local land use trough the diversification of fibre markets. As it can be guessed living and working conditions associated to this practice are quite hard and require high degrees of rusticity and commitment.

Agro-pastoral systems are based on specific agricultural practice whereby animals are mostly raised in open settings, mostly feeding on local natural grazing; several interactions and synergies characterise the combination of farming and livestock systems. 
Agro-pastoralism has proved to be an effective land use for the mountains, drylands, and islands that cover approximately half of the Euro-Mediterranean region. As a main source of food, employment and income it has represented a resilient livelihood system in these marginal territories where the costs for land and labour make this a convenient option compared to other forms of land use, while also playing a critical role in the management of the local rich but fragile natural resource base.

Agro-pastoralism is in fact considered a High Nature Value (HNV) practice, and it is as such increasingly appreciated for the so-called socio-ecosystem services (SES) it provides to the wider society, as it associates quality production with socio-economic opportunities and natural resource protection (Caballero et al. 2009; Nori 2015; Meloni and Farinella 2015a, b; IFAD 2017).

\section{Box: The Socio-Ecosystem Services of Agro-pastoralism}

Pastoralism contributes to the provision of ecosystem services, as it plays a relevant role in maintaining biodiversity. Apart from flora species, agropastoral farmers also contribute to the protection of diversity by rearing autochthonous animal breeds, supporting wildlife habitats and contributing to preserving landscapes. In addition, agro-pastoralism enhances the resilience to hydro-geological risks and natural hazards. Well-grazed vegetation represents an important factor to control erosion, flooding and landslides, as well as a barrier to the spread of forest fires, while enhancing the maintenance of biodiversity and soil quality and reduces the fire risk in permanent crops such as olive groves. The capacities of properly managed pasturelands to absorb carbon and water provide as well a most effective way to store $\mathrm{CO}_{2}$ and to manage rainfall, two ecosystem functions that are increasingly important in a climate perspective (Caballero et al. 2009; Nori and de Marchi 2015; Moreira et al. 2016; Ragkos and Nori 2016).

Apart from economic and ecological aspects, agro-pastoralism in the Mediterranean plays an important socio-cultural and political role as well. By supporting local livelihoods it ensures human presence is maintained in harsh terrains and remote communities, thus contributing to averting socio-economic desertification, with relevant implications on the cultural heritage and territorial identity of local communities. This applies specifically in mountainous areas, 'Europe's ecological backbone', as much as in most EUMed islands, such as Sardinia, Crete, Majorca, Corsica, Peg, Cyprus, etc. Table 6.1 reports on the relevance of agro-pastoralism for the economy and society of Sardinia and Crete.

Although with many differentiations and local characterisations, the embeddedness of agro-pastoralism in local territories and societies contributed in time to shape and maintain the extraordinary cultural and biological diversity that characterizes the Mediterranean countryside, an "historical rural landscapes" 
Table 6.1 Main features of agro-pastoral systems in Crete and Sardinia (year 2016)

\begin{tabular}{l|l|l}
\hline Crete & & Sardinia \\
\hline 0.630 Mils & Human population & $1.663 \mathrm{Mils}$ \\
\hline $1,1 \mathrm{Mils}$ & Sheep population & $3.15 \mathrm{Mils}$ \\
\hline 4.800 & Sheep farms & 11.213 \\
\hline 229 & Average size - heads/flock & 280 \\
\hline $13 \%$ flocks & Transhumance & Few hundreds \\
\hline Autochthonous breeds & Breed & Autochthonous Sarda breed \\
\hline Multifunctional & Production focus & Mainly Pecorino Romano cheese \\
\hline $\begin{array}{l}25 \% \text { at local } \text { mitata } \\
\text { level }\end{array}$ & Dairy processing & Mostly through industries \\
\hline $\begin{array}{l}\text { Mostly through } \\
\text { cooperatives }\end{array}$ & Marketing & 32 coops exist - but mostly con- \\
\hline 4 PDOs & trolled by the industry \\
\hline $\begin{array}{l}\text { Cheese market certification } \\
\text { Albania, Bulgaria }\end{array}$ & $\begin{array}{l}\text { Proportion of immigrants } \\
\text { amongst salaried shepherds }\end{array}$ & 3 PDOs \\
\hline
\end{tabular}

Source: Nori et al. (2017)

(Antrop 1997, 2005; Agnoletti 2013). The complex articulation between pastoral resource management and natural ecosystems is well reflected in Mediterranean landscapes of high natural and cultural value such as the Causses and Cévennes, Dolomites, Picos de Europa, Parco Nazionale degli Abruzzi, Atlas mountains, etc... These offer important opportunities for leisure as well as for tourism development in these regions.

\section{Box: Capitalising on Agro-pastoral Traditions}

A series of projects and initiatives have been launched to enhance pastoral cultures and contribute to their capitalization; these include the Virtual Museum of Transumanzia in Slovenia, the Museum of Transhumancia in Guadalajara and in Aigüestortes in Spain, la Maison du Berger in Provence, the Ecomuseum della Pastorizia in Val Stura and in Sardinia, and other Transhumance musea in the Abruzzi and Molise. The French park of Causses et Cévennes has been acknowledge by UNESCO as a world heritage for Mediterranean agro-pastoral cultural landscape, specifically characterised by pastoral resource management through extensive animal keeping.

These contributions of agro-pastoralism to sustainable societal development are recognized and supported by the Common Agricultural Policy (CAP). CAP plays today a significant role in the budget of agro-pastoral farms. On average CAP financial support might represent today half of the EUMed breeders' annual revenue, with trends and variations changing from a country to another depending on local legislations and implementation of CAP schemes (Nori 2015; Fréve 2014; Ragkos et al. 2016b). 
It is usual to hear amongst agro-pastoral farmers that "we spend today more time in the office than in the field", or to read that "we are considered as landscape gardeners rather than producers of meat and milk" (Nori 2017b: 14) these financial contributions represent a critical resource for this sector (also refer to Brisebarre 2007; Nadal et al. 2010; Pitzalis and Zerilli 2013; Nori 2015). Without this support, sheep, goats and cattle would have already disappeared from most landscapes.

\section{Box: The CAP vis-à-vis Agro-pastoralism}

The recent reforms of the Common Agricultural Policy (CAP) have shifted the focus of public support and rural welfare towards a multifunctional vision of agriculture. In such context agro-pastoralists are increasingly demanded to play their role in managing natural resources and maintaining landscapes, while also contributing to stabilize population and to enhance socio-economic development in marginal settings (Nori and Gemini 2011; Beaufoy and RuizMirazo 2013). Following changing societal demands, CAP policy support has shifted through time from conceiving agro-pastoralists as mostly livestock producers to 'guardians of nature' or suppliers of multifunctional goods and socio-ecosystem services (Marsden 1995; McNally 2001; Vaccaro and Beltran 2007; López-i-Gelat 2013).

The role of the European Union and its CAP remains though contradictory and controversial. The ways CAP addresses the specific problems and needs of agro-pastoralists is not deemed adequate, as for several factors they fall within the same criteria with conventional intensive systems, or not recognised in their diversity - such as for grazing systems in forest areas not accepted for agro-ecological payments; or for the local processing of dairy products, which may at times not comply with European legislations regarding quality standards (e.g. cheese from raw milk), thus hindering the expansion of informal marketing networks and affecting their economic viability (Farinella et al. 2017; Farinella 2018).

Although this public policy is essential to keep these territories populated and productive, the constant decrease in agro-pastoral farms and operators seems to attest that CAP schemes do not seem to be an adequate guarantee for the permanence and the reproduction of these systems.

In this sense, as we will see, the use of low-cost migrant labor is often applied as a strategy to cut down on production costs to tackle the agricultural squeeze. 


\subsection{The Recent Dynamics of Agro-pastoralism in Greece, Spain and Italy}

In the traditional agro-pastoral system the family has typically represented the pillar of farm management, with work organized according to gender and age and aimed at the production and reproduction of the household as well as of the herd. Within a domestic household economy traditional agro-pastoral system is naturally multifunctional in providing a variety of products and services.

As explained in chapter two for the wider agrarian world, the traditional agropastoral model has undergone intense restructuring and reconfiguration in recent decades. Agricultural modernization has led to the expansion of monoculture in lowland areas and the abandonment of several inner and marginal rural settings, less suitable for intensive agriculture. Changes in commercial practices, agricultural policies, societal attitudes and consumption habits have all contributed to transforming not only the agricultural economy, but rural society as a whole. Today most of the livestock products demanded by consumers are increasingly supplied by more intensive production systems, while typical pastoral products such as lambs, ewes' milk and goat cheeses are sourced through imports from other regions (Kerven and Behnke 2011).

EUMed countries (including Portugal and Mediterranean France) hosted in 2015, $39 \%$ and $67 \%$ of the EU-28 sheep and goat population respectively; these were also the highest producers of ewe's milk: first Greece (30.5\% of total milk production in EU); Spain second (27.1\%), and Italy third (21.3\%) (ISMEA 2017). The sheep milk sector will be analysed through the following tables to assess the changes these systems have undergone in recent decades (Figs. 6.2-6.5).

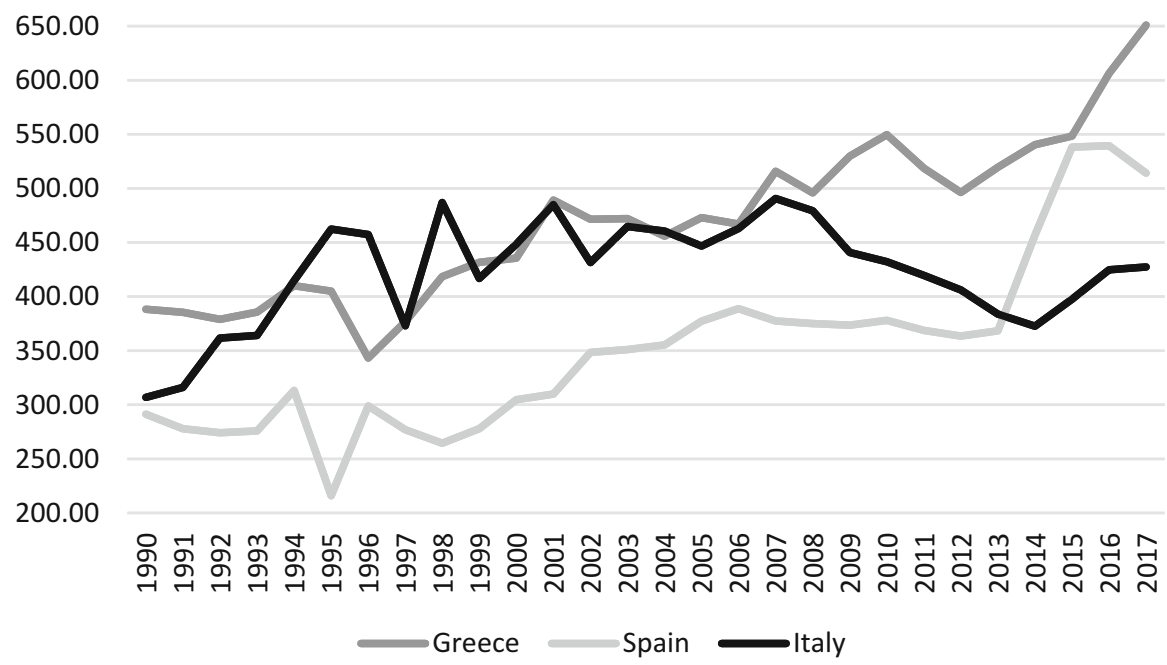

Fig. 6.2 Trend of sheep milk delivered to dairies in Greece, Spain and Italy. Products obtained (1000 t), years 1990-2017. (Source: Our elaboration on EuroStat data) 


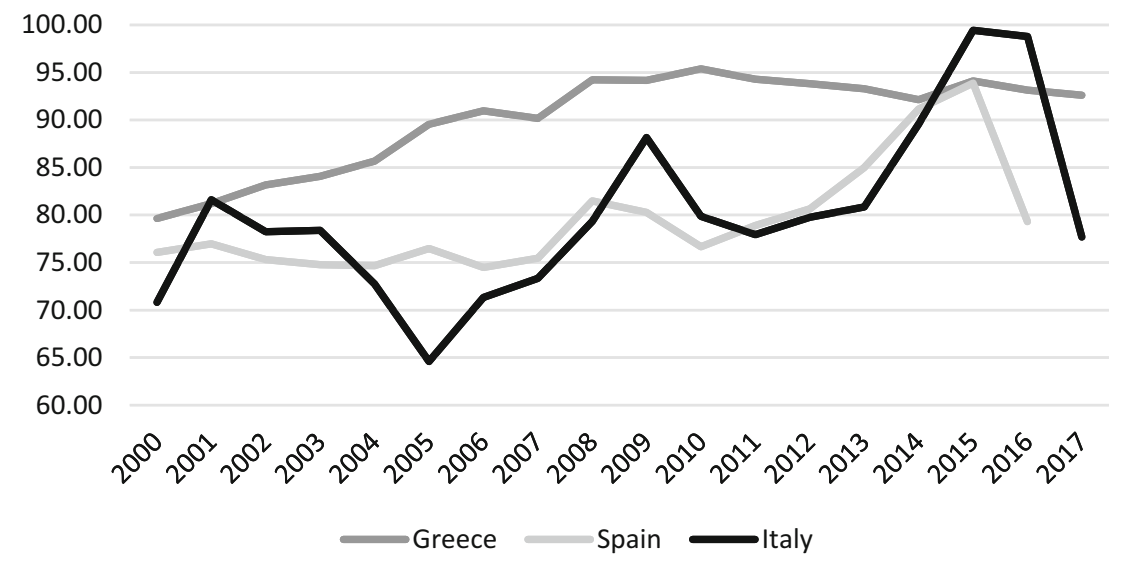

Fig. 6.3 Trends for sheep milk price in Greece, Spain and Italy - $(€ / \mathrm{Kg})$, years $2000-2017$. (Source: Our elaboration on EuroStat data for Greece and Spain, ISMEA for Italy)

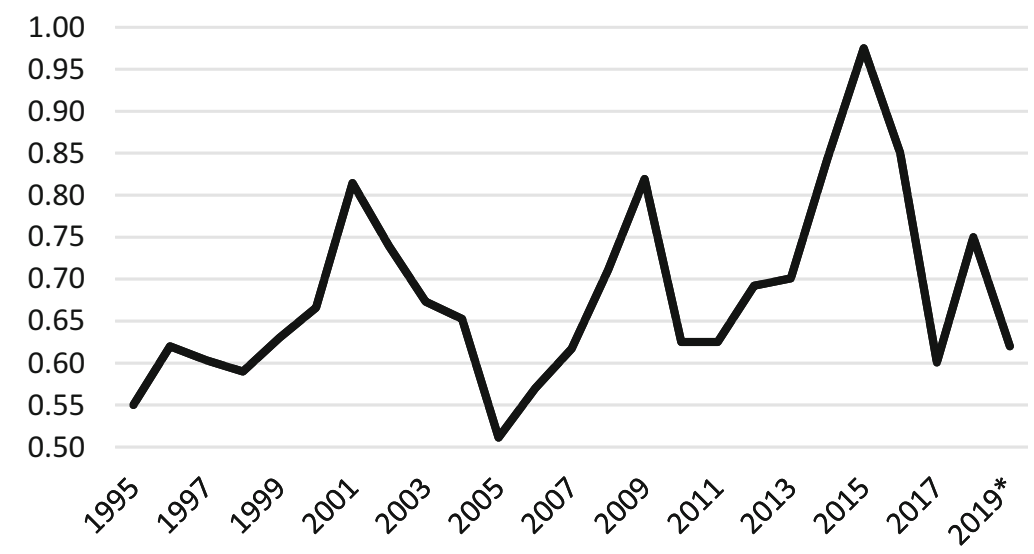

Fig. 6.4 Volatility of the price of sheep milk in Sardinia (€/liter). (Source: Our elaboration on ISMEA data)

The sheep-milk is processed in dairy industries to produce popular cheeses such as the Italian "Pecorino Romano", the Greek "Feta" and the Spanish "Manchego". The fact that these agro-pastoral products are mainly targeted to international markets and within large global food distribution chains represents a factor of economic vulnerability, as global commodities are exposed to high price volatility which affects many agro-pastoral farms (see Fig. 6.3). 


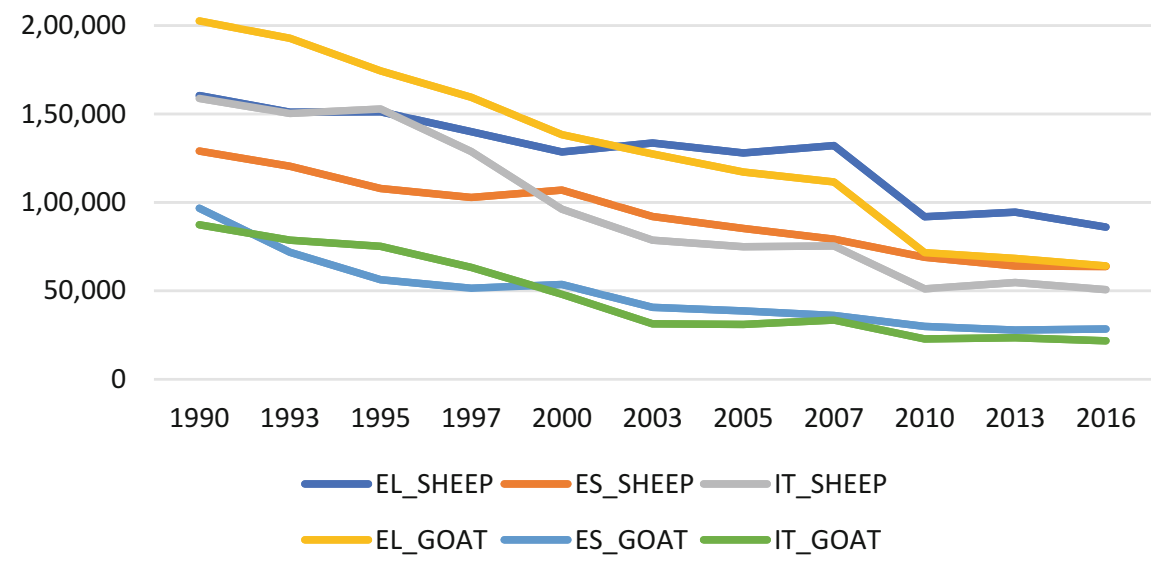

Fig. 6.5 Trends in sheep and goat farms in Greece, Spain and Italy (years 1990-2016). (Map legend: EL Greece, ES Spain, IT Italy. Source: Our elaboration on EuroStat data)

\section{Box: Sardinian Agro-pastoralists Hanging on Global Value-Chains (Farinella 2018, 2019a)}

Sardinia is an Italian region highly specialized in a sheep-breeding that is largely dependent on international markets. According to Istat data, in 2016 Sardinia holds $45.5 \%$ of the national sheep flock (3.3 million sheep) and produces $68.4 \%$ of Italian ewe milk production (2.9 million liters). With the highest ageing index and the lowest birth rate in the world, Sardinia is a region with a depressive demographic dynamic. In 2013, out of a total of 30.260 sheep farmers, over a third were aged above 60 and over $50 \%$ were older than 50 , while only $5 \%$ were aged less than 30 years (Farinella et al. 2017).

Sardinian agro-pastoralism remains semi-extensive, though it is heavily embedded in the "Pecorino Romano" (PR) dairy value chain, a low value-added commodity based on large-scale production for export to the global market, mainly in the U.S.A. (which imports about $80 \%$ of the total PR production) where it is used as "mixed cheese" to improve the taste of industrial food. This makes Sardinian farmers largely dependent on the price of sheep milk, determined in turn by the value of PR in the global market. The PR supply chain is organized in an oligopolistic fashion, with the large processing industries and large-scale distribution brands controlling its sales and imposing the milk purchase price on sheep farmers. Strong fluctuations in the price of sheep milk can be observed, with a periodic and increasingly close frequency of price spikes, which trigger Sardinian livestock farmers to increase the levels of farm exploitation. It is within this vicious circle, that the costs of the market are dumped on the weakest links in the chain.

In 2015, the price of sheep raw milk was around $1 € /$ liter in Sardinia; since 2016 onwards it has gone through important fluctuations, with peaks of $0.60-0.50 € /$ liter, which eventually pushed Sardinian sheep farmers into unusual forms of protest in february 2019 (when the milk price is lowered to $0,60 € /$ liter), such as the pouring of milk on the streets (Simula 2019; Farinella 2019b). The Sardinian case is emblematic of the difficulties faced by farmers in global agrifood chain, which they often participate from a subordinate position. 
Table 6.2 The consistency of the sheep sector in EUMed countries

\begin{tabular}{|c|c|c|c|c|c|}
\hline Country & $\begin{array}{l}\text { Sheep } \\
\text { farms }^{\mathrm{a}} \\
(2016)\end{array}$ & $\begin{array}{l}\text { Sheep } \\
\text { flock }^{b} \\
(2016)\end{array}$ & $\begin{array}{l}\text { Ewes' milk - } \\
\text { products }(\mathrm{Kt})^{\mathrm{a}} \\
(2017)\end{array}$ & $\begin{array}{l}\% \text { meat }^{\mathrm{b}} \\
\text { production } \\
(2010)\end{array}$ & $\begin{array}{l}\% \text { milk }^{\mathrm{b}} \\
\text { production } \\
(2010)\end{array}$ \\
\hline Greece & 86.030 & 8.227 .630 & 427.43 & $15 \%$ & $85 \%$ \\
\hline Spain & 63.730 & 15.862 .160 & 514.20 & $82 \%$ & $18 \%$ \\
\hline Italy & 50.650 & 7.026 .540 & 650.90 & $35 \%$ & $65 \%$ \\
\hline EUMed & 200.410 & 31.116 .330 & & & \\
\hline
\end{tabular}

Sources: ${ }^{\mathrm{a}}$ EuroStat, ${ }^{\mathrm{b}}$ ISTAT, INE, Magrama

Due to these pressures from the institutional and market spheres, the costs related to increasing animal productivity have arisen consistently in latest decades. Further dependence on genetics, agronomic and veterinary sciences as well as through the increasing reliance on market-supplied inputs and intensified animal feed production have also amplified input costs (Farinella 2018, 2019a). However, most agropastoral practices continue to rely on physical labour and manual activity, which is poorly mechanized, and with low productivity compared to other agricultural systems. Productivity rates have often increased more slowly than production costs, which has contributed to increasingly squeeze the sector viability; many farmers have been either forced to close or to deeply restructure their farm, by expanding their herd and re-organising land and labour resources accordingly as a way to adjust cost-benefit ratios (Hadjigeorgiou 2011; Farinella and Meloni 2013; Mattalia et al. 2018; Farinella 2018, 2019a; Theodoridis and Ragkos 2018).

The exploitation of immigrant workers represents for these farms a strategy to contain costs and it is often accompanied by the self-exploitation of the farmers' OWN family work. Different from crop-oriented farms, agro-pastoralists work closely with their labourers and carry out tasks together, with more horizontal and less hierarchical relationships.

The restructuring of the sector following these dynamics has profoundly changed the size of agro-pastoral enterprises and the nature of livestock management. Today there is a marked separation between the managerial and the field work; on the one hand the burdensome administrative components to be compliant with technical requirements and financial assistance, and on the other hand the tending of the livestock.

The classic refrain amongst agro-pastoralists is that " 20 years ago with a flock half size of the present one we had a decent life and we could even make savings and investments. Now with a double-sized flock, it is difficult to make ends meet by the end of the year" (Nori 2017b:12). Official data seem to confirm this perception (refer to Tables 6.3, 6.4, 6.5, and 6.6 and to Figs. 6.5, 6.6, 6.7, and 6.8). The amount of agro-pastoral farms and flocks have decreased (Table 6.3), while the size of those remaining in the business has expanded (Tables 6.4 and 6.6). The decline in agropastoral farms accompanies the marked overall reduction of about $30 \%$ of the EUMed small ruminants' flock in recent decades (FAO database; EuroStat 2016). 


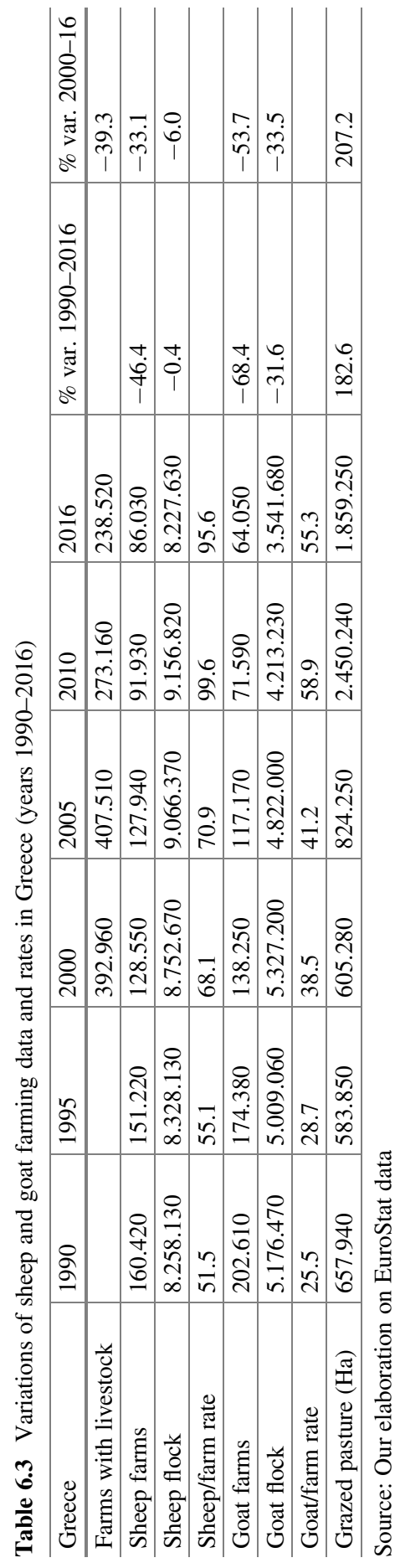




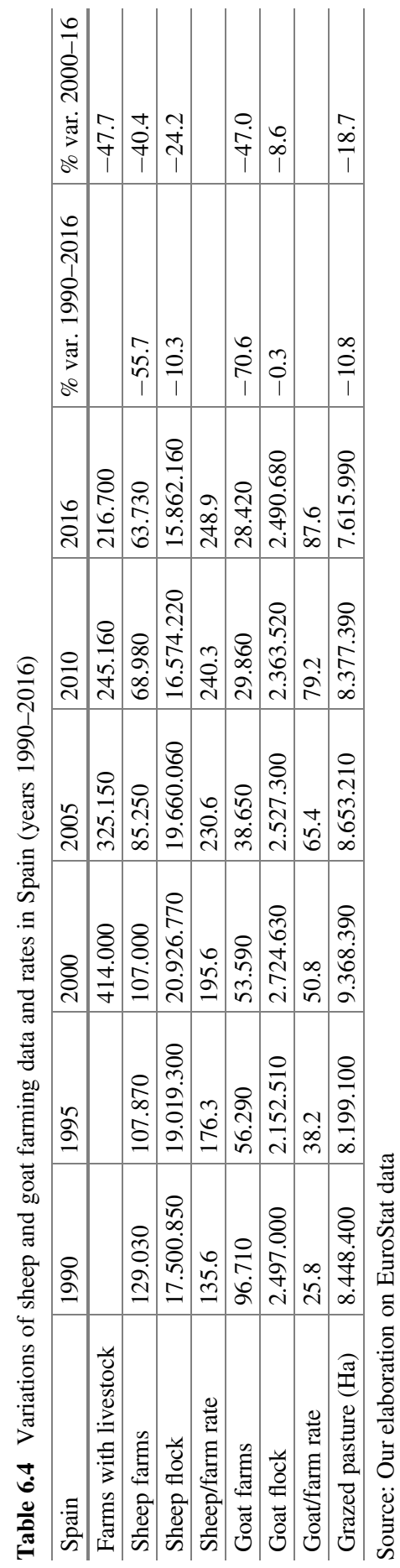




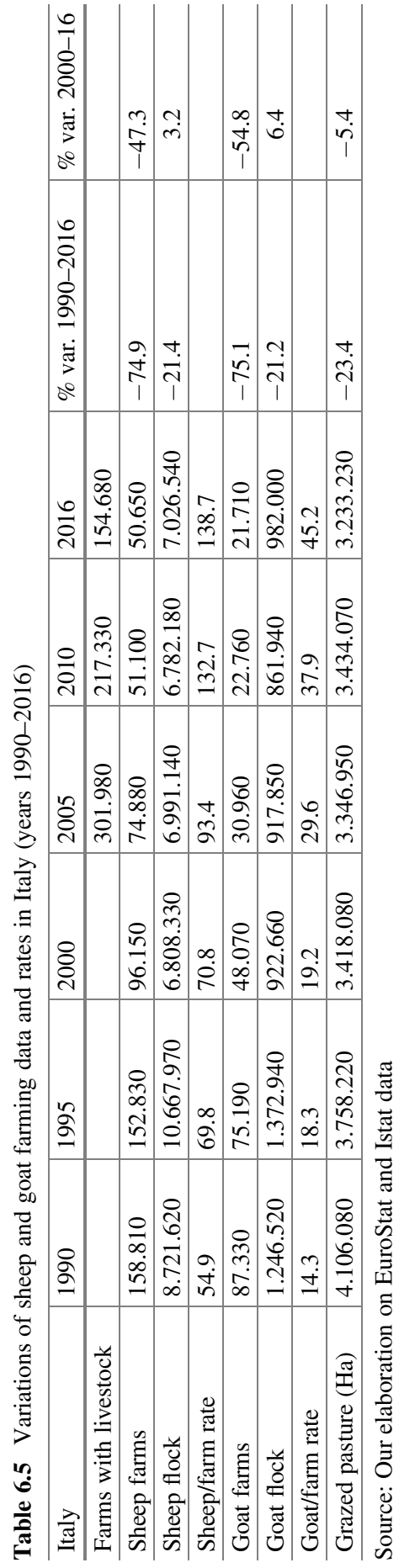


Table 6.6 Utilised agricultural area and permanent grassland in Italy, 2016

\begin{tabular}{l|l|l|l}
\hline & $\begin{array}{l}\text { Utilised agricultural area } \\
\text { UAA }(\mathrm{Ha})\end{array}$ & $\begin{array}{l}\text { Permanent grassland } \\
(\mathrm{Ha})\end{array}$ & $\begin{array}{l}\text { Permanent grass-land/ } \\
\text { UAA (\%) }\end{array}$ \\
\hline Italy & 1.143 .960 & 319.690 & 27.9 \\
\hline North West & 102.000 & 46.770 & 45.9 \\
\hline North East & 177.730 & 49.850 & 28.0 \\
\hline $\begin{array}{l}\text { Central } \\
\text { Italy }\end{array}$ & 178.460 & 52.000 & 29.1 \\
\hline $\begin{array}{l}\text { Southern } \\
\text { Italy }\end{array}$ & 483.960 & 89.990 & 18.6 \\
\hline Islands & 201.820 & 81.100 & 40.2 \\
\hline
\end{tabular}

Source: Our elaboration on EuroStat data

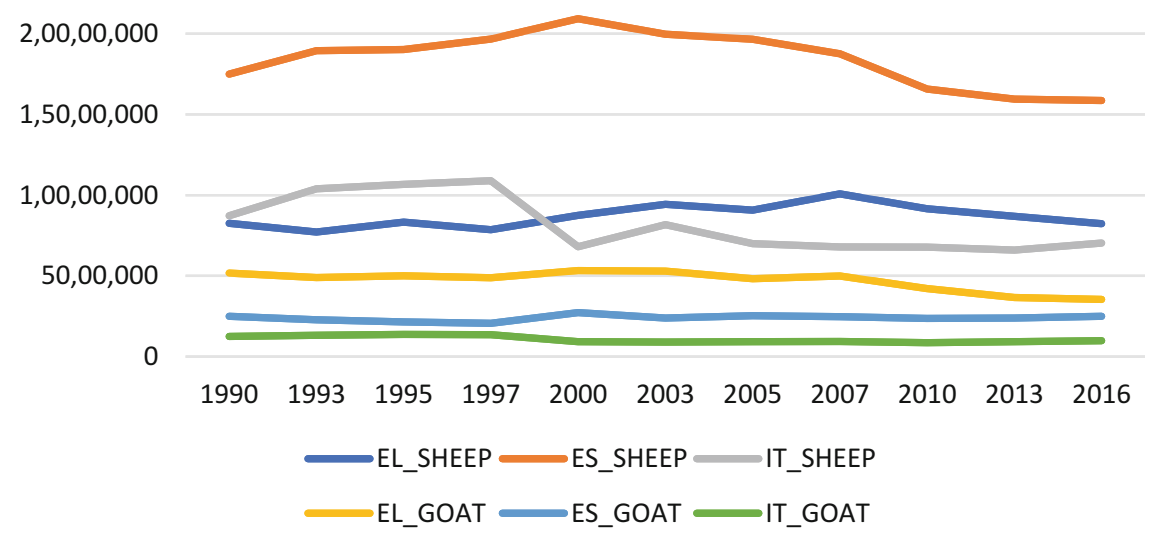

Fig. 6.6 Trends in national sheep and goat flocks in Greece, Spain and Italy (years 1990-2016). (Map legend: EL Greece, ES Spain, IT Italy. Source: Our elaboration on EuroStat data)

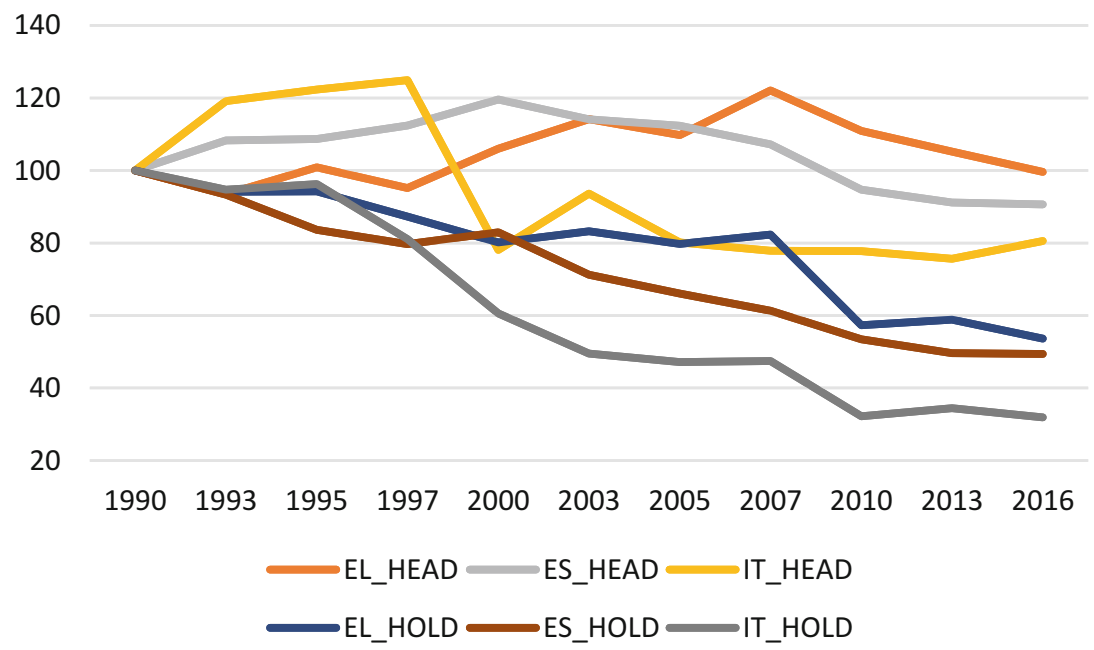

Fig. 6.7 Trends in national sheep flock and sheep farms in Greece, Spain and Italy (years 1990-2016 - index year: $1990=100$ ). (Map legend: $E L$ Greece, ES Spain, IT Italy, HEAD amount of sheep, HOLD amount of sheep farms. Source: Our elaboration on EuroStat data) 


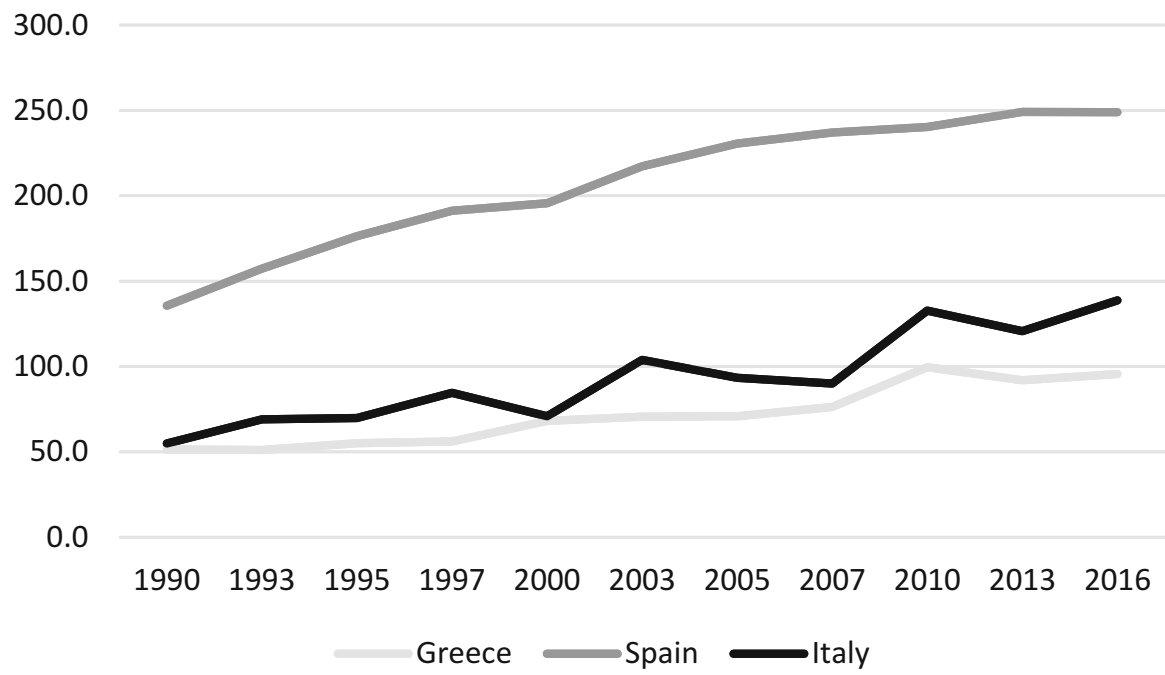

Fig. 6.8 Trend for average sheep farm size (average of sheep number for farm) in Greece, Spain and Italy (years 1990-2016). (Source: Our elaboration on EuroStat data)

We will use here some basic indicators referring to agro-pastoralism in Greece, Spain and Italy in recent decades, to assess the dynamics and trends that have characterised this sector in marginal rural areas and less industrialized regions of the recent decades in the EUMed. These data include the amount of agro-pastoral farms, the consistency of sheep and goats flocks (typically raised in extensive systems) as well as data related to the use of grazing lands.

In Greece, the livestock sector contributes to $28.3 \%$ of the total added value of national agriculture, and it has been particularly affected by recent declining trends. Small ruminant farming is the most important livestock production system in Greece; sheep and goats represent about $75 \%$ of the overall grazing units in the country, contributing significantly to local income and national GDP. Official data indicate that this sector accounts for $27 \%$ of the gross animal production value and $7.2 \%$ of the gross agricultural production value of the country (Hellenic Statistical Authority 2009).

It is specifically relevant in maintaining rural populations and as a main pattern of landscape management in the inner and island territories of the country, where employment opportunities outside livestock faming are limited. In these areas agro-pastoralism employs $17 \%$ of the workforce and accounts for $6.5 \%$ of the gross domestic product (Ragkos et al. 2016a, b).

According to Agricultural Census in Greece, livestock farms have decreased consistently in recent decades, with a drop of 39\% from 2000 to 2016. Sheep are by far the most common livestock (representing about $38 \%$ of the total livestock 
population), but sheep farms have followed the same trends, although variations in sheep units have been changing through time in less linear ways Table 6.3). During the same period permanent grasslands increased consistently $(+200 \%)$, indicating the growing relevance of extensive livestock breeding in some Greek regions during the recent decades.

Agro-pastoralism in Greece is territorially diversified: in Central Greece (Thessaly) as much as in the Northern, mountainous areas (Epirus) a mixed system of transhumance and semi-extensive sheep and goat breeding prevails. In lowlands more intensive sheep farming characterized by high investments and modern infrastructure has emerged especially since the 2000s. In most islands extensive grazing of mostly small ruminants represents a main source of livelihood for many rural communities, through the processing and the sale of Feta cheese through touristic networks (Ragkos et al. 2018).

In Spain, sheep and goat farming represent about a third of the overall livestock farm units in the country. Accession to EU in 1986 and corresponding financial flows had not interrupted the downward trend of traditional farming systems, particularly for livestock. The agricultural holdings with livestock decreased by 47,7\% between 2000 and 2016 (Table 6.4). Data reveal that it was mostly smaller sized farms that disappeared from the landscape. Larger farms with more intensive livestock rearing have increased their stock of cattle and pig, while sheep and goat stock have decreased by $24,2 \%$ and $8,6 \%$ respectively. Territorial diversity is huge in Spain, from the northern Pyrenees, to central mountainous mesta systems, to drier pasturelands in Andalucia and Extremadura. Indications about change in pasturelands use are though similar throughout the country.

Satellite imagery confirms a $-19 \%$ decline in grazed grasslands from 2000 to 2016 all over Spain, mostly due to changes in extensive livestock census, but also because of the different management patterns applied. A similar trend has been observed in dry mountainous areas, where the intensification of management in sheep farms is negatively related to (a) the use of natural grazing resources and to (b) the lack of generational renewal that risks compromising the continuity of most extensive farms. Depopulation and abandonment in these areas are reported to largely affect land use change, with significant impacts on environmental services and public goods (Caballero et al. 2009; Porqueddu et al. 2017).

In Italy, small ruminants breeding is a typical activity in most inner parts of the country, including in the Appenine and Alpine mountainous ranges, and in the islands. Within the period 1990-2016 agro-pastoral farms have undergone a process of concentration and modernization. Though the amount of sheep farms has dramatically dropped $(-74,9 \%)$, during the same period the national sheep flock has decreased to a much lower degree $(-21 \%)$. The average farm size (average of sheep number for farms) has shifted from almost 54,9 heads on average per flock to 138,7 , almost three times more in less than two decades. In the same period, 
grazed pastures have undergone a gradual, continuous and consistent reduction $(-23,4 \%$, Table 6.5).

In 2016 grazing resources such as permanent grasslands and pastures still cover though large part of the agricultural land throughout the country - North West $(32.5 \%)$, North East (24\%), Southern Italy (20.6\%) and Central Italy (18.5\%), and about $40 \%$ of Sardinia and Sicily islands (Table 6.6). While agro-pastoral breeding of sheep, goats and even cattle are widespread in the large marginal territories of the country, territorial differences are many across regions and between Alpine, Apennine and insular settings.

\subsection{Shepherding Labour and Immigrant Workforce in the Mediterranean Agro-pastoralism}

Due to the extensive nature of agro-pastoralism, the work of the shepherd is intense and encompasses both physical labour as well as technical and managerial skills that range from knowledge about the climate, the vegetation, animal physiology and health, the ethology of predators, etc. (refer to Meuret 2010). Most of the shepherd's time is spent in harsh conditions, with limited access to public services, scarce connectivity and few opportunities for leisure and alternative activities. Continuous mobility and processing of milk add burdens to daily mansions, while the growing presence of predators and climatic vagaries represent further hardening factors. The shepherding profession relies thus on several technical and strategic skills, with specific ecological know-how as well as physical endurance.

In recent decades living conditions of shepherds have hardly improved, while working conditions have intensified, through a significant increase in their tasks and responsibilities. At the same time earnings have fallen as a result of competition on the international markets. Sectoral restructuring has thus contributed to creating unattractive conditions for the new generations, who have often decided not to follow their fathers' footsteps, and to avoid engaging in a profession with an uncertain perspective.

Through these lenses one can understand the crisis of agro-pastoral "vocation" and the relative lack of manpower and the problems of generational renewal on EU pasturelands in the Alps, Epirus, Apennines and Pyrenees, which rank among the areas most exposed to the risk of abandonment.

Figure 6.9 and Table 6.7 show that in Italy, Spain and Greece agro-pastoralist are younger than other farmers. Despite this, the problem of generational turnover appears evident, as over $50 \%$ of sheep and goats farmers are older than 55 years.

The challenge related to an aging population and limited generational renewal had already been identified as a priority by the Pastomed program, which in 2007 


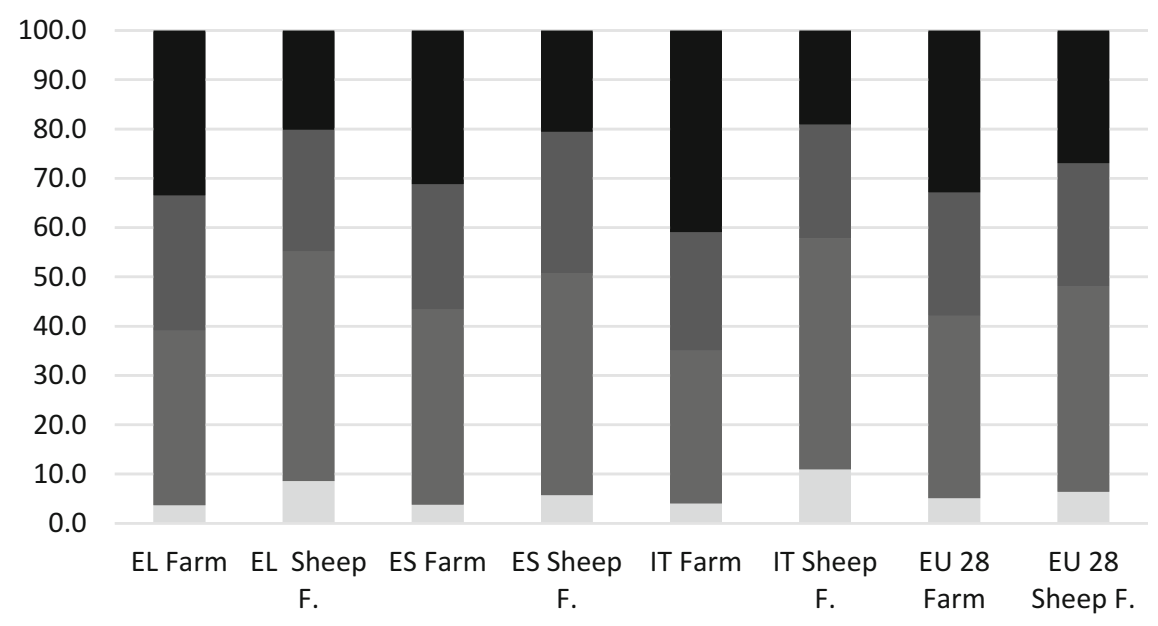

Less than 35 years $\square$ From 35 to 54 years $\square$ From 55 to 64 years 65 years or over

Fig. 6.9 Farm indicators by age of the manager in 2016 (comparison between "average" and "sheep, goats and other grazing livestock" farms). (Map legend: EL Farm Greece Farms, EL Sheep $F$. Greece "sheep, goats and other grazing livestock" farms, ES Farm Spanish Farms, ES Sheep F. Spanish "sheep, goats and other grazing livestock" farms, IT Farm Italian Farms, IT Sheep F. Italian "sheep, goats and other grazing livestock" farms. Source: Our elaboration on EuroStat data)

Table 6.7 Age of the farmers in 2016 and 2013

\begin{tabular}{|c|c|c|c|c|c|}
\hline Country & Year & $\begin{array}{l}\text { Less than } \\
25 \text { years }\end{array}$ & $\begin{array}{l}\text { From } 25 \text { to } \\
34 \text { years }\end{array}$ & $\begin{array}{l}\text { From } 55 \text { to } \\
64 \text { years }\end{array}$ & $\begin{array}{l}65 \text { years or } \\
\text { over }\end{array}$ \\
\hline \multicolumn{6}{|c|}{ Average farmers } \\
\hline \multirow[t]{2}{*}{ Greece } & 2016 & 0.4 & 3.3 & 27.4 & 33.5 \\
\hline & 2013 & 0.8 & 6.1 & 21.6 & 33.3 \\
\hline \multirow[t]{2}{*}{ Spain } & 2016 & 0.2 & 3.6 & 25.4 & 31.2 \\
\hline & 2013 & 0.4 & 4.9 & 25.6 & 29.7 \\
\hline \multirow[t]{2}{*}{ Italy } & 2016 & 0.4 & 3.6 & 24 & 40.9 \\
\hline & 2013 & 0.7 & 4.4 & 24.3 & 37.2 \\
\hline \multirow[t]{2}{*}{ EU 28} & 2016 & 0.5 & 4.7 & 25 & 32.8 \\
\hline & 2013 & 0.8 & 6.7 & 23.6 & 29.6 \\
\hline \multicolumn{6}{|c|}{ Sheep, goats and other grazing livestock farmers } \\
\hline \multirow[t]{2}{*}{ Greece } & 2016 & 0.7 & 7.9 & 24.6 & 20.2 \\
\hline & 2013 & 2.7 & 14.5 & 19.6 & 18.1 \\
\hline \multirow[t]{2}{*}{ Spain } & 2016 & 0.6 & 5.1 & 28.7 & 20.5 \\
\hline & 2013 & 0.8 & 7.4 & 26.0 & 19.7 \\
\hline \multirow[t]{2}{*}{ Italy } & 2016 & 1.2 & 9.8 & 23.1 & 19.1 \\
\hline & 2013 & 2.2 & 11.5 & 21.4 & 16.9 \\
\hline \multirow[t]{2}{*}{ EU 28} & 2016 & 0.7 & 5.7 & 25.0 & 26.9 \\
\hline & 2013 & 1.1 & 8.0 & 23.9 & 24.4 \\
\hline
\end{tabular}

Comparison between "average" and "sheep, goats and other grazing livestock" farms Source: Our elaboration on EuroStat data 
reported "the very high rate of over-55 compared with those under 35 years of age (...) and in many areas, the presence of elderly people 10 times more than young ones!" (Pastomed 2007:18). According to Slow Food, amongst local agricultural products in high danger of extinction, those from extensive livestock systems rank highest (dairy products are first, and meat second in many parts of southern Europe), due to the decrease of human resources (Essedra 2015).

As the local youth is decreasingly interested in working in this sector, the shepherding workforce has also changed, from family members to salaried labourers, and eventually from local workers to foreign ones. Today large parts of EUMed pasturelands are grazed by local flocks accompanied by immigrant shepherds who have come to fill this labour shortage, at a relatively low cost. Even the newly established agro-pastoral farms and enterprises often rely on immigrants' workforce (Circerchia and Pallara 2009; Cicerchia 2012, 2014; Nori and de Marchi 2015).

In Greece there has been a massive influx of immigrants to rural areas in recent decades, especially following the collapse of the Albanian regime and the consequential borders opening in the early 1990s. Important proportions of Albanians came to live and work in mountainous villages of northern Epirus, contributing significantly to the restructuring of the extensive livestock sector and to the local social, economic and demographic fibres (Kasimis and Papadopoulos 2005; Kasimis 2010). These early flows slowly opened the way to shepherds originating from Eastern Europe (Bulgaria), and more recently to workers from Eastern Asia (India and Pakistan). In the Epirus and Peloponnesus immigrants represent today about half of the agro-pastoral salaried workforce; in Crete they account for about a third (Ragkos et al. 2013; Nori 2018).

By providing a skilled workforce at a relatively low cost, immigrant shepherds have contributed to ensuring the maintenance and the reproduction of agro-pastoral enterprises. Due to the shortage of family labour, the recruitment of immigrants has enabled farm women to maintain their domestic role, and younger household members to continue studying and/or looking for employment opportunities outside the agricultural sector (Papadopoulos and Roumpakis 2009; Ragkos et al. 2016a). These contributions have supported on one side the development of large, innovative and specialized dairy farms along the schemes proposed by the CAP, while on the other side they have also enabled the maintenance of more traditional transhumance systems that characterize agro-pastoral resource management in certain parts of the country.

In Spain, immigration from a variety of countries has contributed to the labour reconfiguration of several local agro-pastoral systems. In areas where predation is encroaching, the presence of shepherds is becoming increasingly important to take care of flocks. For example, in the north-eastern Pyrenees, immigrants constitute about half of the salaried shepherding workforce. Traditionally these immigrants originate from Morocco and Romania, but more recent trends indicate a growing 
presence of shepherds issued from Bulgaria, Ukraine, and increasingly Sub-Saharan and Latin-American workers. The ratio of immigrant shepherding workforce decreases to one in three workers in central Spain, in the Castillas, as well as in Galicia and Extremadura, where Portuguese workers are more likely to be found (Nori 2017a, b). Some of these workers have joined some form of training in one of the six pastoral regional schools present in the country.

In Italy the salaried workforce in livestock production is largely and increasingly composed of immigrants, due to the difficulty of recruiting local people. While the presence of immigrant workers is well reported in more intensive livestock farming (Lum 2011), their contribution to the agro-pastoral systems have been only limitedly appreciated (Nori 2016; Farinella et al. 2017).

Immigrants constitute today about two-thirds of the agro-pastoral salaried workforce in most Alpine and Apennine pastures in Italy, where the growing presence of predators has contributed to the reincorporation of shepherds in many inner areas of the country (Nori and de Marchi 2015). In Abruzzo, a region with an important pastoral tradition, official data indicates that nine over ten salaried shepherds are Macedonians or Romanians (Coldiretti 2010). In Sardinia, where agro-pastoral land use covers most of the island territory and whose small ruminants' stock represents over $40 \%$ of the national flock, one every three salaried shepherds is a foreigner, representing a critical resource for reproducing the family farming enterprise (Farinella and Mannia 2017, 2018; Nori 2018; Farinella 2019b).

\section{Box: Shifting Workforce - The Emblematic Example of Sardinian Pastoralism}

In the past being a salaried shepherd (su theracu in Sardinian language) represented a common step in the socio-economic career of local youth, before generating own capacities and money to raise a herd on your own right (Farinella and Mannia 2017, 2018). Today conditions have made this job not attractive for young people who rather prefer emigrating elsewhere in search of employment. It is today up to immigrant workforce to perform the functions related to livestock management and breeding, but also collateral tasks such as clearing lands, building fences, collecting timber, farming animal feed, producing cheese, as well as building or mechanical activities on the farm. By triangulating data from different sources on resident and working populations, estimates attest to about a thousand the Romanians employed in agro-pastoralism in the region in 2016, mostly engaged in lowland mediumsized, semi-intensive sheep farms (Farinella and Mannia 2017, 2018). In the last two years the number of Romanians have decreased, during the milk crisis (Farinella 2019a, b; Simula 2019). 
Most immigrate shepherds originate from other pastoral communities in the Mediterranean, and thus show some skills and capacities related to livestock husbandry. In some regions a process of substitution of a group over another is reported, whereby the Albanians, Macedonians and Moroccans that started working as shepherds in the 1990s have been replaced by Romanians in the 2000s, due to the latters' accession to the EU, and the related facilitation in administrative and mobility terms. More recently an increase of workforce originating from sub-Saharan Africa as well as Eastern Asia is being reported (Nori and López-i-Gelats 2017).

Data and trends in Portugal and France are similar, although the dynamics of immigrants' shepherding workforce have followed different patterns and trajectories. Other agricultural sub-sectors specific to marginal territories show similar dynamics; for example, workers from Eastern Europe and the Balkans account for about $40 \%$ of the forestry workforce in central Italy, and in many cases they provide a crucial contribution to maintain longstanding local, traditional sylvicultural systems (Cicerchia and Pallara 2009; Luisi and Nori 2017).

\subsection{The Conditions of Immigrant Shepherds}

The typical profile of migrants that have come to work as a shepherd in EUMed region is that of a male, aged between 25 and 40, native of a country of the Mediterranean (predominantly from Romania, Morocco, Albania or northern Macedonia), but recently also from Asia (e.g. Pakistan, India), sub-Saharan Africa (e.g. Ghana, Senegal) and even from Latin America (in Spain). Though not necessarily from pastoral areas, the large majority comes from a rural setting and has direct experience in livestock breeding:

We are organised and upon demand we can seek for more workers from our networks, mostly in our villages in north-eastern Romania. There, everybody used to keep sheep. Most households produced their own cheese, that is where we have learnt. We know how to deal with sheep. (TRAMed Interview with a shepherd, Triveneto, April 2015)

History, language, and the networks of migrants have shaped the different migratory patterns. Romanians are mostly found in Italy and parts of Spain, Moroccans in parts of Spain and southern France, and Albanians in Greece. Sociocultural differences aside (e.g. Orthodox or Muslim in predominately Catholic societies), immigrant shepherds are generally appreciated for their technical skills, as well as for their endurance, flexibility and adaptability, in that they accept the working conditions and salary generally rejected by the local population; "they are 
like us 60 years ago" (Nori and López-i-Gelats 2017). Younger shepherds are preferred as they are more likely to learn local languages and follow indications.

Average immigrant shepherds work individually and live in isolated sheepfolds, often in remote areas far from villages and with limited means to move. Cases exist in certain areas where shepherds are seasonal workers, who tend to return home or to work elsewhere when the peak season is over (ie. once the transhumance or the intense milking periods are over).

Salary rates normally range between 600 and 1000 euros per month, for a fulltime engagement, with very limited free time and little holiday. In addition to the salary bed and board are often provided by the farm, though often associated to the sheepfolds. This arrangement enables farmers to underpay workers and to maintain forms of control on them (Farinella and Mannia 2018). Immigrants' revenue is often invested in their home communities, at times on the purchase of family land and livestock, with the hope they would one day get back; this also results from having limited chances to graduate and remain in destination areas.

The contractual arrangements are often quite informal, partial and precarious. Conditions of illegality, limited rights, scarce salary and poor living and working standards represent typical features of workers operating in this grey context, on the margins of a rural world that is already marginal on its own. There are no trade unions, recruitment is carried out exclusively by word of mouth through personal networks and individual arrangements that presents at times exploitative mechanisms (Farinella 2019b).

These elements add to a situation where limited access to land and credit are the main factors inhibiting the capacity and the interest of these workers to remain in this sector. This is further exacerbated by constraints related to residence permits, entrepreneurial licenses and overall citizenship rights, including compliance with CAP procedures and rules, which would enable them accessing precious financial support. In this context, workers see little chance for improving their socio-economic conditions. They often remain a few months or years in this sector, switching between different farms in search of more comfortable living and working conditions. However, the incentives to take over existing farms or establishing new ones remain limited.

The limited formalization of contractual relationships, poor labour conditions and the very scanty prospects for a socio-economic "upgrade" are complementary and inter-twined elements that characterize most Euro-Mediterranean agriculture (Pittau and Ricci 2015; Farinella and Mannia 2018).

The fact that a generational change is accompanied by an ethnic one is not new to the region. Over the last century, Mediterranean pastoralism has witnessed Sardinians colonising abandoned pasturelands in central Italy, southern Spanish herders 
moving to graze the Pyrenees, northern Italian shepherds migrating to Provence and Switzerland, the moves of Valachos and Arvanites flocks and shepherds throughout Greece and Kurdish shepherds in several regions of western Turkey (Lebaudy 2010; Meloni 2011; Nori 2016 - cfr. Table 6.8 and Fig. 6.10). These communities have substantially contributed to keeping pasturelands of destination countries populated, alive and productive.

Compared to past migratory dynamics, today an important difference relates to the difficulties faced by immigrants to graduate socially and economically in their activity. Migrants that have recently come to operate as shepherds in the EUMed have barely improved through time their conditions as workers and much as citizens. Their transition from workers to entrepreneurship and livestock farmers in their own

Table 6.8 Migratory flows of shepherds through the Mediterranean in the twentieth century

\begin{tabular}{l|l|l|l|l|l}
\hline \multirow{2}{*}{$\begin{array}{l}\text { Destination } \\
\text { region }\end{array}$} & \multicolumn{5}{l}{ Origin of migrant shepherds } \\
\cline { 2 - 6 } & Late 1800 & $1950 \mathrm{~s}$ & $1980 \mathrm{~s}$ & $1990 \mathrm{~s}$ & $2000 \mathrm{~s}$ \\
\hline Provence & $\begin{array}{l}\text { Italy and } \\
\text { Spain }\end{array}$ & \multicolumn{2}{|l}{ Morocco and Tunisia } & & Romania \\
\hline Central Italy & & Sardinia & $\begin{array}{l}\text { Morocco and } \\
\text { Tunisia }\end{array}$ & $\begin{array}{l}\text { Albania, } \\
\text { FYROM }\end{array}$ & Romania \\
\hline Pyrenees & $\begin{array}{l}\text { Neighbouring } \\
\text { valleys }\end{array}$ & Andalusia & & Morocco & $\begin{array}{l}\text { Romania, } \\
\text { sub-Saharan Africa }\end{array}$ \\
\hline Turkey & & Kurdistan & & Afghanistan & \\
\hline
\end{tabular}

Source: TRAMED data elaboration

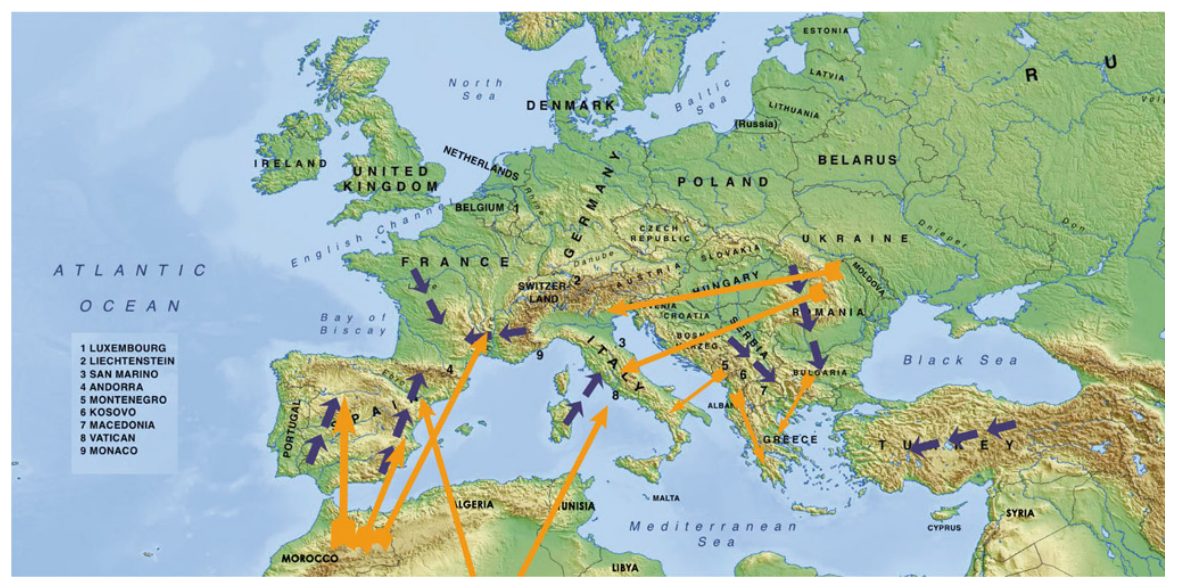

Fig. 6.10 Trajectories of past (darker) and present (lighter) patterns of shepherds' migrations in the Mediterranean. (Source: TRAMED data elaboration) 
right shows very low rates. This in turn constrains the capacity of the incoming population to sustainably contribute to repopulate pastures and to reproduce agropastoralism in the longer term.

\subsection{Stories of Immigrants in Italian Agro-pastoralism}

In this section, some personal stories from the Italian agro-pastoralism are detailed, so to provide a human perspective to the dynamics and processes assessed also with a view to focus on people, individual stories and personal projects.

Italy is a country where Made in Italy agro-food represents a strategic sector and plays a critical economic role through agricultural export and the tourism industry. The Italian dairy sector is representative of the contribution of immigrants to the globally recognised excellence of this sector. ${ }^{1}$ The agro-pastoral immigrant workforce is in fact not only relevant in terms of taking care of herds and flocks, but as well in the dairy processing industry. Apart from the better-known case of the Sikh community with the Parmesan (Lum 2011; Azzeruoli 2014), and the Bengali communities for the buffalo mozzarella, foreign communities play a strategic contribution in the value chains of Fontina and Pecorino cheeses, which are typical regional products issued from pastoral settings. Most representative "made in Italy" cheeses are in fact made by immigrants' hands.

In Valle d'Aosta, almost two thirds of the workers employed in cattle breeding are foreigners. From taking care of the local breed cattle to the processing of milk in the alpine huts (malghe), immigrants largely contribute to the production of the famous Fontina cheese that characterises the region. Formerly almost exclusively Moroccan shepherds, in recent years they have been partially replaced by Romanians. Data from 2014 reported 303 non-EU workers (predominantly Moroccans) and 335 foreign EU workers (predominantly Romanians) officially employed, together with several irregular workers (around 100). Foreign labourers have more than doubled over the last two decades, representing to date about more than two thirds of the salaried shepherding workforce. Living and working conditions are quite harsh, these being main reasons local inhabitants do not seem interested in undertaking this work. In such terms immigrant shepherds do not compete thus with local workers, and their contribution can therefore be said to be essential for maintaining the traditional system of breeding for the production of Fontina DOP (Cicerchia 2014; Nori 2016, 2018).

In Sardinia, usually, Romanians are involved only in the sheep management and in the milking activities, as most shepherds produce milk for processing industries.

\footnotetext{
${ }^{1}$ http://slowfood.com/resistenzacasearia/ita/77/vullnet-alushani-caciocavallo-podolico-delgargano-italia
} 
They often work in pairs and are regulated with seasonal contracts, which expire in summer, when sheep milking is over. Some of them engage in complementary activities to supplement their salary, such as vineyard pruning, harvesting wood and collecting cork.

In multifunctional farms, where sheep-breeding is associated to other activities (agritourism, educational farms, other breeding and agricultural activities) and farmers produce artisanal cheeses in local dairies, Romanians are also directly involved in the dairy processing, including the traditional Fiore Sardo and Pecorino Sardo (Farinella 2019b).

In Sardinia and in other Italian regions, exceptional cases exist where foreign shepherds have engaged and succeeded in scaling up to livestock ownership and farm management. In these experience immigrant shepherds look into opportunities to set up their own flocks, and/or cooperate amongst themselves or with local dwellers in sharing land, subsidies or credit assets (Farinella and Mannia 2017; Farinella et al. 2017; Nori 2018).

For instance, M., a Romanian shepherd who came to Italy 10 years ago, initially worked without a contract or insurance. Seven years ago, he got a contract which finally made him eligible for Italian citizenship, which is needed to register as an entrepreneur and to legally own a flock. With his savings, he was able to accumulate a few animals each year, which he kept within the flock of his employer. Recently, he and his employer have been talking about jointly managing a common flock. They plan to share the costs and responsibilities, as well as the profits. With an established business, M. will be able to bring his wife and children to Italy. Other examples of such socio-economic graduation exist where two immigrants have shared resources and responsibilities or in areas where pasture lands are communal and therefore more easily accessible.

Another similar case is the story of G., a Romanian shepherd in Sardinia. G. started as a worker in a sheep farm. After a short time he decided to try to start his own business using the networks that he created in the area and the relationship of trust with his employer, with whom they started a cooperation. Following local practices whereby farms could be split amongst siblings or relatives to enhance and extend CAP support. G. started his own activity, though he still works with his previous Sardinian employer. The Romanian shepherd continues to live in a sheepfold house, made available by his now Sardinian colleague. All the activities (bringing the animals to the pasture, the milking and the cultivation of the land) continues to be carried out together by the Sardinian and the Romanian shepherd, using the structures of the former. However, G. is no longer an employee, he does not receive a salary; he is in charge of his own milk, while also receiving CAP support. He does not pay the rental, but he is charged with his work for the land and structures he utilizes. This is an example of very interesting cooperation, which is based on local forms of reciprocity and non-monetised exchanges. In this way positive externalities are created for both individuals as well as for the local 
community they live in. G. has the dream to save to be able to buy a piece of land in Sardinia.

Another example of multi-functional rural entrepreneurship by migrants is that of the organic farm "La Capra Felice", launched in Trentino in 2010 by a young Ethiopian woman. After studying in Italy, she returned to her country of origin to create a project of sustainable agriculture, but she had eventually been forced to leave the country because of its struggle against the excessive power of food multinationals. When she returned to Italy, she started a multifunctional agricultural activity, in which she raises goats of the native breed, the Mòchena spotted, at risk of extinction and other locally typical animals.

She produces directly and sells locally her own diversified homemade organic sheep-goat cheeses, through short supply chain networks. Some of her dairy products have gained the Slow Food dairy resistance award. The choice of an extensive breeding, based on wild grazing and on particularly frugal native breeds, allows the milk to have a high organoleptic quality (which derives from the biodiversity of natural pastures) and to organize a diversified agricultural activity, which sustainable in either economic terms as well as agro-ecological terms. She organizes training activities and educational farming with the primary school and contribute to the production of services and welfare in rural areas, for example through the reception of a refugee (Sivini 2019).

\subsection{Conclusions}

Agro-pastoralism represents an increasingly appreciated practice in Europe and elsewhere for its quality products as well as for the important public goods it contributes, in the form of socio-ecosystem services. These recognitions are rewarded through public subsidies and market pricing. Despite growing societal acknowledgement and appreciation, agro-pastoralism is though decreasingly practiced by the local populations; the consistent decrease in farms and flocks holds important consequences on the livelihood systems as well as on the natural resource management of marginal territories.

Immigrants have proved to be a strategic resource to fill the shepherding labour gaps left by the declining, ageing and decreasingly interested local population. Notwithstanding the important contributions received through public policies, and no matter what type of entrepreneurial strategy pursued to cope with the sector restructuring, immigrant shepherds have shown to represents a strategic asset for this agricultural practice, by providing a skilled labor force at a relatively low cost. Without foreign workers, many agro-pastoral farms would face today great difficulty in pursuing their activities and in so maintaining EUMed marginal territories alive and productive.

Yet oftentimes the conditions under which these dynamics are taking place are not enabling the sustainable reproduction and development of agro-pastoralism in the region, as the conditions and the opportunities immigrant shepherds enjoy are not 
conducive towards their integration into agro-pastoralism in more consistent and structured ways. In a lose-lose situation, immigrant shepherds do not graduate in socio-economic terms thus to evolve into farmers themselves, while elderly farmers do not find people capable of taking over their farms when they retire. Society at large witnesses the disappearance of flocks, the abandonment of marginal lands, together with the loss of quality products and services, despite important degrees of public investments.

This case reflects more in general the complexity and contradictions of immigrant presence in rural regions and in the agriculture sector - in that foreign workers are willing to accept working conditions and salaries usually rejected by the local people, their presence is only temporary, with relevant implications for local patterns of rural development.

The cases where shepherds have graduated to livestock farmers represent rare exceptions, and important opportunities to capitalise upon, with a view to secure a more sustainable rural society.

\section{Appendix: The Presence of Immigrants in EUMed Agro-pastoralism}

\begin{tabular}{|c|c|c|c|c|c|}
\hline Region & $\begin{array}{l}\text { Main } \\
\text { production }\end{array}$ & $\begin{array}{l}\% \text { foreign } \\
\text { on total } \\
\text { salaried } \\
\text { shepherd }\end{array}$ & $\begin{array}{l}\text { Origin country } \\
\text { of most of } \\
\text { them }\end{array}$ & $\begin{array}{l}\text { Average } \\
\text { monthly } \\
\text { salary (€) }\end{array}$ & Source \\
\hline \multicolumn{6}{|l|}{ Italy } \\
\hline Abruzzo & Milk & $90 \%$ & $\begin{array}{l}\text { Macedonia, } \\
\text { Romania, } \\
\text { Albania }\end{array}$ & 800 & Coldiretti (2010) \\
\hline Triveneto & Meat & $70 \%$ & Romania & 800 & TRAMed \\
\hline Piedmont & $\begin{array}{l}\text { Meat and } \\
\text { milk }\end{array}$ & $70 \%$ & $\begin{array}{l}\text { Romania, } \\
\text { Moldavia }\end{array}$ & 800 & $\begin{array}{l}\text { TRAMed; } \\
\text { Cicerchia and } \\
\text { Pallara (2009) and } \\
\text { Cicerchia (2014) }\end{array}$ \\
\hline Val d'Aosta & Milky cows & $70 \%$ & $\begin{array}{l}\text { Romania, } \\
\text { Morocco }\end{array}$ & 2000 & Cicerchia (2014) \\
\hline Sardinia & Milk & $35 \%$ & $\begin{array}{l}\text { Romania, } \\
\text { Morocco }\end{array}$ & $500-600$ & $\begin{array}{l}\text { Farinella and } \\
\text { Mannia (2017); } \\
\text { TRAMed }\end{array}$ \\
\hline Calabria & Milk & $35 \%$ & $\begin{array}{l}\text { Kurdistan, } \\
\text { Pakistan, India }\end{array}$ & $500-600$ & $\begin{array}{l}\text { Cicerchia and } \\
\text { Pallara (2009) }\end{array}$ \\
\hline \multicolumn{6}{|l|}{ Greece } \\
\hline Thessaly & Milk & $50 \%$ & $\begin{array}{l}\text { Albania, } \\
\text { Bulgaria, } \\
\text { Romanian } \\
\text { Vlachs }\end{array}$ & $400-600$ & Thales, Domestic \\
\hline
\end{tabular}




\begin{tabular}{|c|c|c|c|c|c|}
\hline Region & $\begin{array}{l}\text { Main } \\
\text { production }\end{array}$ & $\begin{array}{l}\% \text { foreign } \\
\text { on total } \\
\text { salaried } \\
\text { shepherd }\end{array}$ & $\begin{array}{l}\text { Origin country } \\
\text { of most of } \\
\text { them }\end{array}$ & $\begin{array}{l}\text { Average } \\
\text { monthly } \\
\text { salary (€) }\end{array}$ & Source \\
\hline Peloponnese & Milk & $40 \%$ & $\begin{array}{l}\text { Albania, } \\
\text { Bulgaria, } \\
\text { India, Pakistan }\end{array}$ & $400-600$ & Thales, Domestic \\
\hline Crete & Milk & $35 \%$ & $\begin{array}{l}\text { Albania, } \\
\text { Bulgaria, } \\
\text { India, Pakistan }\end{array}$ & $400-600$ & Thales, TRAMed \\
\hline \multicolumn{6}{|l|}{ France } \\
\hline \multirow[t]{2}{*}{ Provence } & Meat & $\begin{array}{l}\text { Mostly dur- } \\
\text { ing winter } \\
\text { for large } \\
\text { flocks }\end{array}$ & $\begin{array}{l}\text { Romania } \\
\text { Morocco, } \\
\text { Tunisia }\end{array}$ & 1400 & $\begin{array}{l}\text { TRAMed; Fossati } \\
\text { (2015) }\end{array}$ \\
\hline & & $\begin{array}{l}\text { Mostly on } \\
\text { summer } \\
\text { pastures }\end{array}$ & $\begin{array}{l}\text { Other regions } \\
\text { of France or } \\
\text { Northern } \\
\text { Europe }\end{array}$ & $1500-2500$ & $\begin{array}{l}\text { TRAMed; Meuret } \\
\text { (2010) }\end{array}$ \\
\hline Pyrenees & Milk & $\begin{array}{l}\text { Few sala- } \\
\text { ried } \\
\text { shepherds }\end{array}$ & $\begin{array}{l}\text { Quite limited } \\
\text { phenomenon }\end{array}$ & & Meuret (2010) \\
\hline $\begin{array}{l}\text { Maritime } \\
\text { Alps }\end{array}$ & Meat & $20 \%$ & Romania & & TRAMed \\
\hline Corse & $\begin{array}{l}\text { Milk and } \\
\text { meat }\end{array}$ & & Morocco & & Terrazzoni (2010) \\
\hline \multicolumn{6}{|l|}{ Spain } \\
\hline $\begin{array}{l}\text { Valencia } \\
\text { Community }\end{array}$ & & $70 \%$ & Morocco & 600 & AVA (2009) \\
\hline $\begin{array}{l}\text { Catalan } \\
\text { Pyrenees }\end{array}$ & Meat & $55 \%$ & $\begin{array}{l}\text { Romania, } \\
\text { sub-Saharan } \\
\text { Africa }\end{array}$ & $6-700$ & Nadal et al. (2010) \\
\hline $\begin{array}{l}\text { Aragon } \\
\text { Pyrenees }\end{array}$ & Meat & $60 \%$ & $\begin{array}{l}\text { Morocco, } \\
\text { Romania, } \\
\text { Bulgaria, } \\
\text { Ukraine }\end{array}$ & & TRAMed; \\
\hline Andalucia & & & $\begin{array}{l}\text { Romania, } \\
\text { sub-Saharan } \\
\text { Africa }\end{array}$ & & TRAMed; \\
\hline Castillas & $\begin{array}{l}\text { C. Léon } \\
\text { meat } \\
\text { C. Mancha } \\
\text { milk }\end{array}$ & $35 \%$ & $\begin{array}{l}\text { Morocco, } \\
\text { Romania, } \\
\text { Bulgaria, } \\
\text { Portugal }\end{array}$ & & $\begin{array}{l}\text { TRAMed; } \\
\text { Plataforma }\end{array}$ \\
\hline $\begin{array}{l}\text { Basque } \\
\text { country }\end{array}$ & Milk & & Romania & 1000 & TRAMed; \\
\hline Galicia & & & Portugal & & TRAMed; \\
\hline Extremadura & & & Portugal & & TRAMed; \\
\hline
\end{tabular}

Source: TRAMed project 


\section{References}

Agnoletti, M. (Ed.). (2013). Italian historical rural landscapes. Cultural values for the environment and rural development. Dordrecht: Springer.

Antrop, M. (1997). The concept of traditional landscapes as a base for landscape evaluation and planning. The example of Flanders. Landscape and Urban Planning, 38(1-2), 105-117. https:// doi.org/10.1016/S0169-2046(97)00027-3.

Antrop, M. (2005). Why landscapes of the past are important for the future. Landscape and Urban Planning, 70(1-2), 21-34. https://doi.org/10.1016/j.landurbplan.2003.10.002.

A.V.A. (2009). Una Jornada sin Inmigrantes. Informe. Asociación Valenciana de Agricultores http://www.levante-emv.com/sociedad/2009/12/06/jornada-inmigrantes/658140.html

Azzeruoli, V. (2014). Legami tra pianure. Gli intermediari nella migrazione dei panjabi indiani in Italia. Phd thesis, Univeristy o Padua. http://paduaresearch.cab.unipd.it/7004/

Beaufoy, G., \& Ruiz-Mirazo, J. (2013). Ingredientes para una nueva Política Agraria Común en apoyo de los sistemas ganaderos sostenibles ligados al territorio. Revista Pastos, 43(2), 25-34.

Braudel, F. (1982, V ed., ed.or.1949). La Méditerranée et le monde méditerranéen à l'époque de Philippe II. Paris: Armand Colin.

Brisebarre, A. M. (2007). Bergers et transhumances. Romagnat: De Borée.

Caballero, R., Fernández-González, F., PérezBadia, R., Molle, G., Roggero, P. P., Bagella, S., D'Ottavio, P., Papanastasis, V. P., Fotiadis, G., Anna, S. A., \& Ioannis, I. I. (2009). Grazing systems and biodiversity in Mediterranean areas: Spain, Italy and Greece. Revista Pastos, 39(1), $9-152$.

Campbell, J. K. (1964). Honour, family and patronage. In A study of institutions and moral values in a Greek mountain community. Oxford: Clarendon.

Cicerchia, P. (Ed.). (2012). Indagine sull'impiego degli immigrati in Agricoltura in Italia. Roma: INEA.

Cicerchia, P. (Ed.). (2014). Indagine sull'impiego degli immigrati in Agricoltura in Italia. Roma: INEA.

Cicerchia, M., \& Pallara, P. (Eds.). (2009). Gli immigrati nell'agricoltura italiana. Roma: INEA. http://www.red-network.eu/resources/toolip/doc/2011/11/04/inea\%2D\%2D-gli-immigratinellagricoltura-italiana\%2D\%2D-2009.pdf

Coldiretti. (2010). Complemento al Dossier immigrazione Istat 2010. https://www.coldiretti.it/ archivio/istat-nelle-stalle-dove-si-ottiene-il-latte-per-il-parmigiano-reggiano-1-lavoratore-su-3e-indiano-12-10-2010

ELSTAT. (2009). Hellenic statistical office. Athens: Coincise Statistical Yearbook.

Essedra. (2015). Environmentally sustainable socio-economic development of rural areas. Slow Food project funded by the EU Instrument for Pre-accession Assistance (IPA) Civil Society Facility.

Eurostat. (2016). Agriculture, rural development statistics. Luxembourg: Eurostat.

Farinella, D. (2018). La pastorizia sarda di fronte al mercato globale. Ristrutturazione della filiera lattiero-casearia e strategie di ancoraggio al locale. Meridiana, 93. https://www.viella.it/rivista/ $9788833131597 / 4251$

Farinella, D. (2019a). The case of the Pecorino Romano dairy production chain in Sardinia, Italy. In M. Migliorini (Ed.), FOOD TRACK. A transparent and traceable supply chain for the benefit of workers, businesses and consumers: The role of a multisectoral approach to industrial relations and corporate social responsibility (pp. 130-163). Rome: CGIL.

Farinella, D. (2019b). Le ragioni e la lotta dei pastori sardi. Gli Asini, 62, 17-22.

Farinella, D., \& Mannia, S. (2017). Migranti e pastoralismo. Il caso dei servi pastori romeni nelle campagne sarde. Meridiana, 88, 175-196. https://www.viella.it/rivista/9788867288601/3970

Farinella, D., \& Mannia, S. (2018). «Mi chiamo Serban e non sono il romeno di nessuno, sono il romeno di me stesso». Pratiche di assoggettamento e soggettivazione tra pastori sardi e servi pastori romeni. Etnografia e ricerca qualitativa, 3, 405-426. https://doi.org/10.3240/92124. 
Farinella, D., \& Meloni, B. (2013). Dalla tradizione all'innovazione: prospettive e opportunità delle filiere agroalimentari territorializzate. In B. Meloni \& D. Farinella (Eds.), Sviluppo rurale alla prova, dal territorio alle politiche (pp. 127-154). Torino: Rosenberg \& Sellier.

Farinella, D., Nori, M., \& Ragkos, A. (2017). Change in Euro-Mediterranean pastoralism: Which opportunities for rural development and generational renewal? In C. Porqueddu, A. Franca, G. Molle, G. Peratoner, \& A. Hokings (Eds.), Grassland reources for extensive farming systems in marginal lands: Major drivers and future scenarios (Volume 22 grassland science in Europe) (pp. 23-36). Wageningen: Wageningen Academic Publishers.

Fossati, L. (2015). De l'émigration à l'immigration. Savoir-faire berger en Valle Stura di Demonte. In: G. Lebaudy, B. Msika, B. Caraguel (editors), L'alpage au pluriel, Cardère éditeur.

Fréve, E. R. (2014). L'élevage ovin français : entre finalité domestique et mission de service public, la transformation du métier de berger en Provence. In G. Gallenga (Ed.), De la porosité des secteurs public et privé, Une anthropologie du service public en Méditerranée (pp. 33-50). Aix-en-Provence: Presse Universitaire de Provence.

Hadjigeorgiou, I. (2011). Past, present and future of pastoralism in Greece. Pastoralism: Research, Policy and Practice, 1, 24.

IFAD. (2017). Sending money home: Contributing to the SDGs, one family at a time. Rome: International Fund for Agricultural Development (IFAD).

ISMEA. (2017). Settore ovicaprino, Scheda di settore. http://www.ismeamercati.it/lattiero-caseari/ latte-derivati-ovicaprini

Kasimis, C. (2010). Demographic trends in rural Europe and migration to rural areas. Agri Regioni Europa, 6/21. https://agriregionieuropa.univpm.it/it/content/article/31/21/demographic-trendsrural-europe-and-international-migration-rural-areas

Kasimis, C., \& Papadopoulos, A. G. (2005). The multifunctional role of migrants in the Greek countryside: Implications for the rural economy and society. Journal of Ethnic and Migration Studies, 31(1), 99-127. https://doi.org/10.1080/1369183042000305708.

Kerven, C., \& Behnke, R. (2011). Policies and practices of pastoralism in Europe. Pastoralism: Research, Policy and Practice, 1, 28. https://doi.org/10.1186/2041-7136-1-28.

Le Lannou, M. (1979). Pastori e contadini di Sardegna. Cagliari: Edizioni della Torre.

Lebaudy, G. (2010). Shepherds from Piedmont in Provence: Career paths and mobility. In Proceedings of the XVI international oral history conference between past and future: Oral history, Memory and meaning. Prague.

López-i-Gelats, F. (2013). Is mountain farming no longer viable? The complex dynamics of farming abandonment in the pyrenees. In S. Mann (Ed.), The future of mountain agriculture (Springer geography). Berlin: Springer. https://doi.org/10.1007/978-3-642-33584-6_7.

Luisi, D., \& Nori, M. (2017). Gli immigrati nella Strategia Nazionale per le Aree Interne, dalle Alpi agli Appennini. In A. Membretti, I. Kofler, \& P. P. Viazzo (Eds.), Per forza o per scelta. L'immigrazione straniera nelle Alpi e negli Appennini. Roma: Aracne.

Lum, K. D. (2011). The quiet Indian revolution in Italy's dairy industry. Firenze: European University Institute.

Marsden, T. (1995). Beyond agriculture? Regulating the new rural spaces. Journal of Rural Studies, 11(3), 285-296. https://doi.org/10.1016/0743-0167(95)00027-K.

Mattalia, G., Volpato, G., Corvo, P., \& Pieroni, A. (2018). Interstitial but resilient: Nomadic Shepherds in Piedmont (Northwest Italy) amidst spatial and social marginalization. Human Ecology, 46, 747-757. https://doi.org/10.1007/s10745-018-0024-9.

Mattone, A., \& Simbula, P. (Eds.). (2011). La pastorizia mediterranea Storia e diritto (secoli $X I-X X)$. Roma: Carocci.

McNally, S. (2001). Farm diversification in England and Wales. What can we learn from the farm business survey? Journal of Rural Studies, 17(2), 247-257. https://doi.org/10.1016/S0743-0167 (00)00050-4.

Meloni, B. (1984). Famiglie di pastori: continuita e mutamenti in una comunita della Sardegna Centrale 1950-1970. Torino: Rosenberg \& Sellier.

Meloni, B. (2011). Le nuove frontiere della transumanza e le trasformazioni del pastoralismo. In A. Mattone \& P. F. Simbula (Eds.), La Pastorizia Mediterranea (pp. 1051-1076). Roma: Carocci. 
Meloni, B., \& Farinella, D. (2015a). L'evoluzione dei modelli agropastorali in Sardegna dagli anni cinquanta ad oggi. In L. Marrocu, F. Bachis, \& V. Deplano (Eds.), La Sardegna contemporanea (pp. 447-473). Roma: Donzelli.

Meloni, B., \& Farinella, D. (2015b). Pastoralismo e filiera lattiero casearia, tra continuità ed innovazione: un'analisi di caso. Meridian, 84, 1-26.

Meuret, M. (2010). Un savoir-faire de bergers. Versailles: Editions Qua Beaux livres.

Moreira, O., Carolino, N., \& Beloet, C. (2016). Climatic changes: Scenarios and strategies for the livestock sector in Portugal. In CIHEAM. Watch Letter 37 - Mediterranean agriculture and climate change. Impacts, adaptations, solutions. https://www.ciheam.org/uploads/attachments/ 278/WL_37_PDF_Complet.pdf

Nadal, S. E., Ricou, I. J., \& Estrada, B. F. (2010). Transhumàncies del segle XXI. La ramaderia ovina i la transhumància a l'Alta Ribagorça. Temes d'Etnologia de Catalunya, 20.

Nori, M. (2015). Pastori a colori. Agri Regioni Europa 11/43. https://agriregionieuropa.univpm.it/it/ content/article/31/43/pastori-colori

Nori, M. (2016). Shifting Transhumances: Migrations patterns in Mediterranean pastoralism. In CIHEAM. Watch Letter 36 - Crise et resilience en la Mediterranee. www.iamb.it/share/ integra_"les_lib/"les/WL36.pdf

Nori, M. (2017a). Migrant Shepherds: Opportunities and challenges for Mediterranean. Pastoralism Journal of Alpine Research, 105/4. https://rga.revues.org/3544

Nori, M. (2017b). Immigrant Shepherds in Southern Europe. E-paper, Heinrich Böll Stiftung Foundation. https://www.boell.de/en/agriculture-food-production-and-labour-migration-south ern-europe

Nori, M. (2018). Agriculture and rural territories in the Mediterranean: The case for mountainous communities. In MEDITERRA 2018 - Inclusion and migration challenges around the Mediterranean. Paris: CIHEAM.

Nori, M., \& de Marchi, V. (2015). Pastorizia, biodiversita e la sfida dell'immigrazione: il caso del Triveneto. Culture della sostenibilità, 15, 78-101.

Nori, S., \& Gemini, M. (2011). The common agricultural policy vis-à-vis European pastoralists: Principles and practices. Pastoralism, 1, 27. https://doi.org/10.1186/2041-7136-1-27.

Nori, M., \& López-i-Gelats, F. (2017). Relevo generacional e inmigrantes en el mundo pastoril: el caso del Pirineo catalán. Paper presented at the CSIC conference in Madrid.

Nori, M., Ragkos, A., \& Farinella, D. (2017). Agro-pastoralism as an asset for sustainable Mediterranean Islands. In K. Jurcevic, L. Kaliterna Lipovcan, \& O. Ramljak (Eds.), Mediterranean Issues, Book 1, Imagining the Mediterranean: Challenges and perspectives (pp. 135-147). Vern: Institute of Social Sciences Ivo Pilar.

Papadopoulos, T., \& Roumpakis, A. (2009). Familistic welfare capitalism in crisis: The case of Greece (ERI Working Paper Series, WP-09-14). ERI, University of Bath, UK.

Pastomed. (2007). Le pastoralisme méditerranéen, situation actuelle et perspectives: modernité du pastoralisme méditerranéen. Rapport final du projet Interreg III PastoMED, Manosque.

Pernet, F., \& Lenclud, G. (1977). Berger en corse: essai sur la question pastorale. Grenoble: PUG.

Pittau, F., \& Ricci, A. (2015). Agricoltura e migrazione nel contesto dei muovi mercati globali. Dialoghi mediterranei, 12. www.istitutoeuroarabo.it/DM/agricoltura-e-immigrazione-nelcontesto-dei-nuovi-mercati-globali/

Pitzalis, M., \& Zerilli, F. (2013). Il giardiniere inconsapevole. Pastori sardi, retoriche ambientaliste e strategie di riconversione. Culture della sostenibilità, 6, 12 .

Porqueddu, C., Franca, A., Molle, G., Peratoner, G., \& Hokings, A. (2017). Grassland reources for extensive farming systems in marginal lands: Major drivers and future scenarios (Volume 22 grassland science in Europe). Wageningen: Wageningen Academic Publishers.

Ragkos, A., \& Nori, M. (2016). The multifunctional pastoral systems in the Mediterranean EU and impact on the workforce. Options Méditerranéennes, Série A. Séminaires Méditerranéens 114 (15). Proceedings of the FAO-CIHEAM workshop Ecosystem services and socio-economic benefits of Mediterranean grasslands, Orestiada, Greece.

Ragkos, A., Mitsopoulos, I., Siasiou, A., Skapetas, V., Kiritsi, S., Bambidis, V., Lagka, V., \& Abas, Z. (2013). Current trends in the transhumant cattle sector in Greece. Scientific Papers Animal Science and Biotechnologies, 46(1), 422-426. 
Ragkos, A., Siasiou, A., Galanopoulos, K., \& Lagka, V. (2014). Mountainous grasslands sustaining traditional livestock systems: The economic performance of sheep and goat transhumance in Greece. Options Méditerranéennes, 109, 575-579.

Ragkos, A., Koutsou, S., Tsivara, T., \& Manousidis T. (2016a). The operation of Pomak livestock farms in Northern Evros, Greece. Options Mediterraneennes, Serie A: Mediterranean seminars, pp. 341-344.

Ragkos, A., Koutsou, S., \& Manousidis, T. (2016b). In search of strategies to face the economic crisis: Evidence from Greek farms. South European Society and Politics, 21, 319-337. https:// doi.org/10.1080/13608746.2016.1164916.

Ragkos, A., Koutsou, S., Theodoridis, A., Manousidis, T., \& Lagka, V. (2018). Labor management strategies in facing the economic crisis. Evidence from Greek livestock farms. New Meditterranean Journal, 17(1), 59-72. https://doi.org/10.30682/nm1801f.

Ravis-Giordani, G. (1983). Bergers Corses. In Les communautés rurales du Niolu. Marseille: Edisud.

Sandu, D. (2005). Emerging transnational migration from Romanian villages. Current Sociology, 53(4), 55-82. https://doi.org/10.1177/0011392105052715.

Simula, G. (2019, February 15). Should we cry over spilled milk? The case of Sardinia. In Pastoralism, uncertainty and resilience. A blog about learning from pastoralists on how to respond to uncertainty. https://pastres.wordpress.com/2019/02/15/should-we-cry-over-spilledmilk-the-case-of-sardinia/

Sivini, S. (2019). Azienda agricola "La Capra Felice": l'esperienza di una donna etiope in Trentino. In RRN (Rete Rurale Nazionale). Terreni d'integrazione (pp. 48-50). 3(31).

Terrazzoni, L. (2010). Etrangers, Maghrébins et Corses: vers une ethnicisation des rapports sociaux? La construction sociale, historique et politique des relations interethniques en Corse. Ecole doctorale Economie, organisations, société Paris 10 (Nanterre).

Theodoridis, A., \& Ragkos, A. (2018). Greece. Unfair trading practices and market outcomes in the Greek dairy sector and the role of hired labor in its development. In M. Migliorini (Ed.), FOOD TRACK. A transparent and traceable supply chain for the benefit of workers, businesses and consumers: The role of a multisectoral approach to industrial relations and corporate social responsibility (pp. 13-54). Rome: CGIL.

Vaccaro, I., \& Beltran, O. (2007). Consuming space, nature and culture: Patrimonial discussions in the hyper-modern era. Tourism Geographies, 9, 254-274. https://doi.org/10.1080/ 14616680701422715 .

Open Access This chapter is licensed under the terms of the Creative Commons Attribution 4.0 International License (http://creativecommons.org/licenses/by/4.0/), which permits use, sharing, adaptation, distribution and reproduction in any medium or format, as long as you give appropriate credit to the original author(s) and the source, provide a link to the Creative Commons license and indicate if changes were made.

The images or other third party material in this chapter are included in the chapter's Creative Commons license, unless indicated otherwise in a credit line to the material. If material is not included in the chapter's Creative Commons license and your intended use is not permitted by statutory regulation or exceeds the permitted use, you will need to obtain permission directly from the copyright holder.

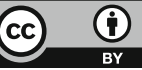

